\title{
Appropriateness of Elements that Support the Integration of HIV and AIDS Education in Teacher Education Programmes in Zambian Colleges of Education
}

\author{
Edith Jere-Bedding, Oswell C. Chakulimba, Emmy. H. Mbozi \\ Lecturer, University of Zambia, School of Education, EPSSE Department, Lusaka, Zambia
}

\begin{abstract}
This article focuses on the appropriateness of elements that support the integration of Human Immuno-Deficiency Virus (HIV) and Acquired Immune Deficiency Syndrome (AIDS) education into teacher education programmes in Zambian colleges of education. The purpose of this article is to present findings on how appropriate the content, teaching methods and learner assessments as elements were in four colleges of education. This article is based on one research question extracted from a PhD thesis titled "An Analysis of the Integration of HIV and AIDS Education in Teacher Education Programmes of Zambia: A Case of Four Selected Colleges of Education. "This study employed the descriptive survey research design. Data were collected from a heterogeneous sample of 90 respondents. The study established that some sections of the content, methodology and assessment elements were not suitable for the age groups that the teacher trainees were going to teach. Furthermore, the contents were inadequately covered due to time constraints. With regard to teaching methods, interactive methodologies were encouraged in form of songs, drama, sketches, road shows and role plays. Learner assessments were not adequately managed in the secondary and primary teacher education programmes because HIV and AIDS education was taught only as a cross-cutting issue.
\end{abstract}

Keywords: Integration, HIV and AIDS, Teacher Training Programmes, Cross-cutting Issue, Content, Methods of teaching and learning, Learner Assessments and elements.

\section{INTRODUCTION}

The content, methods of teaching and learner assessments are highly significant elements in the teaching of HIV and AIDS education in teacher education programmes. Teaching materials are key to teaching of HIV and AIDS education. Most teachers in Zambia have neither been trained to deal with HIV and AIDS nor been provided with appropriate teaching and learning materials. As a result, the teachers are not knowledgeable enough to pass on correct and complete information to students (Chiwela and Mwape, 1999; Molambwe, 2000).

This study was centered on Primary Teacher Education and Secondary Teacher Education courses found in colleges that were sampled. At the time of conducting this research, Zambia had recorded 16 public colleges of education and 18 private colleges of education, 34 in total (MoGE, 2013). The main focus of this study was on four affiliate colleges of the University of Zambia, out of the 29 affiliated private and public colleges of education of which three have acquired University status whereas two, out of the three of these still remain affiliates of the University of Zambia.

\subsection{Background}

The HIV and AIDS pandemic has been known to be the leading cause of death in sub-Saharan Africa. In order for Zambia to address this pandemic, HIV and AIDS education has been integrated into the Teacher education Programmes as a cross cutting issue to be dealt with in all the six study areas with the view to help curb the scourge (Nzioka and Ramos, 2008). The integration of HIV and AIDS education into the teacher education programmes was designed to address the concerns around the high prevalence rates of HIV and AIDS deaths in education and other government sectors across Zambia, which, in 2015 stood at 1,300,000 (one million three hundred) people living with HIV and AIDS out of an estimated population of 15 million people (UNAIDS, 2015).

A United Nations Educational Scientific and Cultural (UNESCO) report indicated that there was limited available information to date on the integration of HIV and AIDS education in teacher 
education programmes. Most of the information that is available does not offer hard data on measuring such programmes for their effectiveness (UNESCO, 2006). According to Meidema (2006) UNESCO identified five different approaches in which HIV and AIDS could be integrated in a regular curriculum such as a stand-alone subject, integrated in one main carrier subject, as a cross curricular subject, infused into the curriculum and as an extra curriculum topic approaches. In this study it was revealed that Zambia is using a combination of extra curriculum and infused into the curriculum approaches. Fully integrating HIV and AIDS into the curriculum means that specific time is allocated to the subject and that learning outcomes are assessed and accredited.

\subsection{Research Question}

The core question of the study looked at: 'How appropriate is the content, methods and learner assessment elements that support HIV and AIDS education in teacher training programmes?'

\section{Literature REVIEW}

It was discovered from literature reviewed that the content, methods and learner assessment elements that support HIV and AIDS education in teacher training programmes were not adequately managed. This resulted in HIV and AIDS Education not to be fully taught to teacher trainees (Kelly, 2000). Reviewed literature also indicated that in most instances content was not adequately taught. The methods used when HIV and AIDS education was taught mostly centred on interactive methodologies. Nzioka and Ramos, (2008) in another study support this finding regarding Teacher Colleges of education exploration of interactive ways of teaching HIV and AIDS education to teacher trainees.

It was also established that there was lack of assessments, such as tests, assignments and examinations to evaluate the students' understanding of HIV and AIDS education. This was confirmed by Chiwela and Mwape, (1999) and Molambwe, (2000) who stated that college lecturers or teachers were not knowledgeable enough to pass on correct and complete information to students. This was clearly supported in this study because assessments were not given, and in cases where they were given these were not marked and as a result learners got no feedback. This is an indication that probably even the teachers themselves were not knowledgeable enough on issues of HIV and AIDS education.

\section{Methodology}

In order to answer the core research question, the following methods were used:

\subsection{Design and Sampling}

This study was conducted in Lusaka, Southern and Central provinces of Zambia. The study employed the descriptive survey research design. In using the descriptive survey research design the study took into consideration the different characteristics of people sampled. The study applied qualitative research orientation and collected data by interviewing the selected sample to represent the population under study. The sample was randomly and heterogeneously selected through the lottery method.

The sampling frame had all the names of respondents written on pieces of paper including their subject areas giving a sample size of 90 respondents.

\subsection{Data Collection Instruments}

Data collection instruments used were questionnaires, structured and unstructured interview guides, observational checklists, focus groups discussion guides and field notes. The secondary data was derived from journal articles and books and reports.

\subsection{Data Analysis}

Qualitative Solutions and Research (QSR) Nvivo 11, a qualitative analysis computer software package was used to sort and analyse data thematically through cross case analysis, whereas a Statistical Package for Social Sciences version 16 (SPSS) was used to process data by generating frequency tables and charts.

\section{ETHical Consideration}

Ethical approval was sought from The Ethics Committee of the University of Zambia for ethical clearance. In order to uphold the fundamental principles of human research ethics, that is, respect of persons, beneficence and justice, the researcher allowed the respondents to fill in a consent form to participate in the study. None of the participants were coerced into participating into the study. 


\section{RESUlTS AND DiscuSSION}

In the act of learning three processes take place: Acquisition of new information, transformation of knowledge acquired and assessing of the learning processes (Bruner, 1980). When students enrol for teacher education studies they look forward to acquiring as much knowledge as possible so that when they become experts they can disseminate this information to their learners. When this is not feasible the student teachers become disoriented and fail to perform. In this study it was established that new knowledge was acquired, HIV and AIDS was taught whereas learner assessments were not adequately managed, it appeared that because this was not adequately done what was actually learnt could not be measured. A student teacher requires to discern that whatever is communicated is adequately assessed through tests, assignments and examinations. When assessments are not given students feel indignant and complain as was deduced in this study. It is appropriate and decent that students get feedback from whatever is being taught so that they know how they are progressing in their studies.

One officer at the Ministry of Education said that HIV and AIDS is not examinable at colleges of Education, he attributed this to the fact that teaching and learning materials were not available and most lecturers only focused on core subjects. The Ministry of Education officer suggested that the only way to minimise on the lack of examination in this area was to have core-subjects and HIV and AIDS education combined.

\subsection{Appropriateness of Content}

The participants were asked if lecturers experienced any challenges in teaching HIV and AIDS education. Some respondents felt that the content was not properly packaged and hence needed repackaging. This was because some subjects such as Mathematics, English, History, Religious Education and Geography did not make mention of HIV and AIDS education in their subject areas at all. Whereas French, Civic Education, Physical Education, Sociology of Education, Guidance and Counselling as well as Environmental education had some aspects of HIV and AIDS education integrated within the subjects. The content ranged from how HIV and AIDS is acquired to consequences of the virus, as well as cultural and traditional practices that influence the delivery of HIV and AIDS content.

The study revealed that it was considered taboo for elders to teach young children about issues pertaining to sex and HIV and AIDS, the study further revealed that some lecturers and teachers felt that some of the content was not suitable for certain age groups that the teacher trainees were going to teach upon completion of their training. The issue of cultural and traditional practices was also observed by Chikwanda, (2015) in Breidlid, Cheyeka and Farag, (2015) (Eds). Another issue that surfaced was the issue of not covering the content due to time constraints, (Kelly, 2002) also recognised the issue of lack of curricular time and orientation in addressing HIV and AIDS education. In some instances the time table was already overloaded with other subjects hence, it was difficult to include HIV and AIDS education. HIV and AIDS was being taught as a cross-cutting issue especially in primary and secondary teacher training programmes. Some lecturers also suggested that their fellow lecturers should be encouraged to handle both content and methodology because what was obtaining at the moment was that content was handled by different lecturers and methods of teaching by different lecturers. This made it very challenging for the learners to understand the information. There are a number of factors that regulate what methods to use to achieve a given learning outcome, (Muzumara, 2011). In this situation it was what content and methods were used to teach as well as the type of learner assessments applied to measure the level of understanding among the learners.

Some student teachers felt that too much talk on HIV and AIDS publicly was not a good idea as people misunderstood the messages. They further reported that expertise in HIV and AIDS education was important contrary to only having basic information on the subject to enable one teach effectively. Some respondents mostly lecturers and teacher trainees felt that some of their colleagues taught using only information that they were familiar and comfortable with to teach. Hence, this mode of teaching led to selective teaching which was not in any way beneficial to the student teachers as recipients of the knowledge. This was also reported by Banda and Mulenga (2015).

Table two below shows that the majority of the student teachers representing 51.6 per cent of the sample indicated that they were not sure whether the content was adequately packaged or not for them to go out to teach. A very small number representing 12.9 per cent indicated that the content was adequately packaged. During the focus group discussion, one student talked about the issue of materials not being adequate for teaching. 
Edith Jere-Bedding et al.

Table2. Is the content adequately packaged to prepare student teachers to go out and teach?

\begin{tabular}{|l|l|l|l|l|}
\hline Column1 & Frequency & Percentage & Valid Percentage & Cumulative Percentage \\
\hline Definitely & 4 & 12.9 & 14.3 & 14.3 \\
\hline Definitely not & 8 & 25.8 & 28.6 & 42.9 \\
\hline Not Sure & 16 & 51.6 & 57.1 & 100 \\
\hline Missing & 3 & 9.7 & & \\
\hline
\end{tabular}

Restless Development is an NGO that partnered with the Government of the Republic of Zambia to help disseminate information on HIV and AIDS to all teacher training colleges. This organisation brought different peer- educators to colleges of education each year to teach on HIV and AID education (which) helped to combat HIV and AIDS as well as to deter further proliferation in the communities.

\subsection{Methods Used in Teaching HIV and AIDS Education}

The study revealed that interactive methodologies through games such as: shomba and agode, agode nichisilu, which are Zambian game songs were used to teach on HIV and AIDS to all learners, especially those taking physical education subjects. Educating Our Future, (MoE, 1996) also recommended interactive methods of teaching in the promotion of life skills. It was also reported that in most schools HIV and AIDS is mention at assemblies, and in each subject lesson. This was meant to help impact some HIV and AIDS knowledge to those lecturers who lacked HIV and AIDS knowledge. The attitude of most of the lecturers as well as some student teachers towards HIV and AIDS education was also another factor that contributed to lack of HIV and AIDS education. It was also reported that there was need to fuse HIV and AIDS into other courses because somebody who is living with HIV and AIDS might shun the course or lecture on the basis of HIV and AIDS subject being monotonous.

The study further revealed that sex education was not well received in most rural communities especially where teachers were the ones who talked about it. Most parents saw this interaction with teachers as another way through which teachers incited their children to have sex with them. Time allocated on the teaching of HIV and AIDS education was another major factor that disadvantaged the lecturers who wanted to teach this subject. It was reported that the timetable was already overloaded with the core subjects leaving no time for other new subjects such as HIV and AIDS education. Some respondents reported that the fact that HIV and AIDS was being handled as a cross cutting issue meant that it was integrated in all the subjects areas.

One student at a Christian teachers' college of education shocked everyone in a focus group when he asked whether clergy men and women such as sisters (Nuns) and Fathers (Priests) can also get infected with the virus since they did not marry. This was an indicator that knowledge on HIV and AIDS was still minimum. The Southern and Eastern Consortium for Monitoring Educational Quality (SACMEQ) III project research results affirmed the fact that teacher and pupil knowledge on HIV and AIDS was minimum, the consortium therefore recommended that the government of Zambia should address this issue, especially regarding prevention education programme focusing on the upper grades of primary schools (Musonda, 2011). Since most of the teachers who teach these children undergo primary teachers training course in colleges of education it is imperative that the student teachers are well trained in HIV and AIDS education.

Some college principles in this study favoured having the HIV and AIDS content taught through drama and street shows. They felt that this was the best way of disseminating information on HIV and AIDS. It was also reported that since the content being taught was only basic, there was need for lecturers to become more skilful than they were so that they could adequately teach on HIV and AIDS. It was suggested that group teaching be encouraged to remove the notion of un-skilfulness. As far as most of the respondents were concerned HIV and AIDS education has not been fully integrated into the various core subjects. It was further suggested that HIV and AIDS education be taught as a stand-alone subject, for effectiveness and to complete the integration.

\subsection{Learner Assessments}

The majority of respondents reported that assessments in terms of tests, assignments and examinations were not given in most subjects that had the integration of HIV and AIDS education within the core subjects. Another revelation that was made in this study was that the assessments in both primary and 
secondary teacher training programmes were not adequately managed because being taught as a cross cutting issue meant that some lecturers did not include the HIV and AIDS education in the tests and examinations for students. According to Zambia Education Curriculum Framework (MoE, 2013) HIV and AIDS was taught as a cross cutting issue so as not to overload or fragment the curriculum because doing so would have meant that the curriculum would be ineffectively implemented. This somewhat conflicts with UNESCO, (2008) documented regarding the integration of HIV and AIDS, which stipulated that the integration of HIV and AIDS should have examination questions included in HIV and AIDS education.

\section{Conclusion}

In conclusion the appropriateness of content, methods of teaching and learner assessment elements that supports the integration of HIV and AIDS education in teacher education programmes were inadequate in most subject areas. This was because HIV and AIDS education cuts across many subject areas such as Sociology of Education, Mathematics, English, History, Geography, Environmental Science, Civic Education, Religious studies etc leaving it fragmented in an already overloaded curriculum. This made the delivery of content difficult. Time constraint was another factor that made it impossible for the content to be well taught. MoE (2013) states that cross-cutting issues when integrated in the curriculum should not be unduly fragmented or over-loaded or else the curriculum will not be implemented effectively. This somewhat implies that HIV and AIDS education is already marginalized by the technocrats and policy makers. This study also revealed that some educators, for fear of being stigmatized with the HIV and AIDS virus by their learners, shunned lecturing on the integration of HIV and AIDS education even though it appeared on their course outline.

It was reported that some lecturers did not want to teach on HIV and AIDS because they did not have the skills and knowledge on the subject and so they could not teach on some issue that they themselves did not understand. This led to selective teaching, where a lecturer only taught what they knew and were comfortable to lecture on. The interactive methods were employed to help teach on HIV and AIDS education was well appreciated by both the learners and the lecturers themselves. Learner assessments were partly ignored according to the results of this study. Lastly some subject areas were already overloaded with information in their core subjects; therefore, some participants in this study recommended that HIV and AIDS education be taught as a stand- alone subject where the lecturers and learners would pay more attention to the subject.

\section{RECOMMENDATIONS FOR FURTHER STUDY}

1. It is recommended that the Ministry of Education with relevant stakeholders who are experts in HIV and AIDS education should train more peer educators to help deliver HIV and AIDS related messages in order to reduce on the risk behaviours among the teacher trainees and lecturers as well.

2. It is recommended that Policy makers and technocrats revisit the policy on management and mitigation on HIV and AIDS in the education sector so that it is not only mainstreamed into the existing curriculum and offered across all levels of education and integrated as a stand-alone subject.

\section{REFERENCES}

Banda, M. and Mulenga, C. (2015) Teacher Education and HIV and AIDS: Investigating Teacher Education Position in the Teaching of HIV and AIDS and Life Skills Education: A Case of one Primary Teacher Training College in the Copperbelt Province of Zambia. Vol 2. Issue 9, September, 2015. ISSN 2349-0373(print) 2349(online) www.arcjournals.org retrieved on $19 / 05 / 16$ at $21.53 \mathrm{hrs}$.

Chikwanda, T (2015) HIV and AIDS and Teacher Education in Zambia. In: A. Breidlid, A.M. Cheyeka, and A.I. Farag, (Eds) Perspectives on Youth, HIV/AIDS and Indigenous Knowledges in Africa (pp. 61-76). Rotterdam: Sense Publishers.

Kelly, M.J., (2000) "What HIV and AIDS can do to Education and What Education can do to HIV and AIDS. "Lusaka: University of Zambia Press. 
Ministry of Education (1996) Education Policy. “Education Our Future”. Lusaka: MOE, Government Printers.

Musonda, B., (2011) Pupil and Teacher Knowledge about HIV and AIDS in Zambia. SACMEQ. Southern and Eastern Africa Consortium for Monitoring Educational Quality. Lusaka: Ministry of Education.

Nzioka, C and Ramos, L., (2008) Training Teachers in HIV and Aids Context: Experiences from Ethiopia, Kenya, Uganda and Zambia: Nairobi.

MOESVTE., (2013)Education Curriculum Framework. Lusaka: Curriculum Development Centre.

UNESCO, Booklet 3: Educator Development and Support. Good Policy and Practice in HIV \& AIDS and Education (booklet series). Paris, UNESCO: 2008.

\section{AUTHORS' BIOGRAPHY}

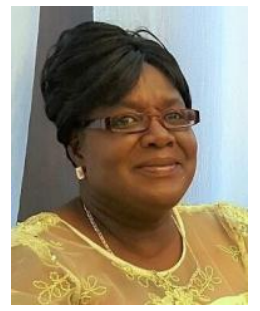

Jere-Bedding, E., is currently a special research fellow at the University of Zambia. Her research interests are sociology of education, social psychology, teacher education and HIV and AIDS education.

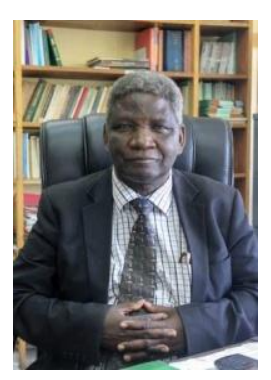

Chakulimba, O.C. is currently Dean of School of Education at the University of Zambia. His research areas are Status of teachers, HIV and AIDS and Teacher Education. Student's Perceptions of a Good Teacher, Theoretical Perspectives in Sociology of Education, Determinants of Social Stratification in a Non-Western Society. New Students Expectations of Life in the University of Zambia.

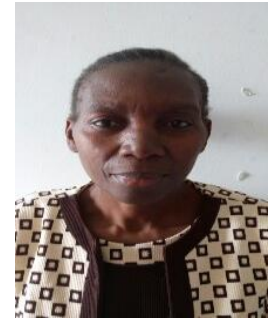

Mbozi, E.H. is currently the Assistant Dean Postgraduate in the school of Education at the University of Zambia. Her research interests are in Adult Education, Gender Studies, HIV and AIDS and Teacher Education. 